\title{
The Neuer Markt as an institution of creation and destruction
}

\author{
David B. Audretsch • Erik E. Lehmann
}

Published online: 22 April 2008

(C) Springer Science + Business Media, LLC 2008

\begin{abstract}
The market for publicly traded equity is the heart of a modern capitalist system. In particular, the market for newly listed firms is in turn a bellwether for the public equity market because the entry gives firms expanded access to capital, allowing them to emerge and grow. On the other hand, stock markets also serve as an institution to reallocate productive resources from non-surviving to surviving firms. We describe the Neuer Markt - a special segment of the Frankfurt Stock Exchange in Germany - as an institution to foster the creation of new firms and their destruction.
\end{abstract}

Keywords Neuer Markt · Firm survival · Entrepreneurship

JEL Classification $\mathrm{G} 32 \cdot \mathrm{L} 11 \cdot \mathrm{M} 13 \cdot \mathrm{C} 14$

D. B. Audretsch

Max Planck Institute, Jena, Germany

e-mail: audretsch@mpiew-mpg.jena.de

D. B. Audretsch

Indiana University, Bloomington, IN, USA

D. B. Audretsch

Center for Economic Policy Research, London, England

D. B. Audretsch

Department Entrepreneurship, Growth and Public Policy, Kahlaische Strasse 10, 07745 Jena, Germany

E. E. Lehmann $(\bowtie)$

Management and Organization, University of Augsburg, Universitaetsstr. 16,

86159 Augsburg, Germany

e-mail: erik.lehmann@wiwi.uni-augsburg.de 


\section{Introduction}

There is a long and extensive literature showing that a bank-based financial system, i.e. a system where banks are the dominant financial organizations, offers inadequate financing to young and innovative firms (Lehmann and Neuberger 2001; Audretsch and Lehmann 2004a, b). Although there is overwhelming evidence that banks as financial intermediaries play a major role in the reduction of agency costs, they may fail to provide debt when the degree of asymmetric information and the project risk are too high. In the 1980 s, this system was widely praised for providing stable, longterm financing to small and medium sized firms and was frequently recommended for emulation in other countries (Vitols 2001; Lehmann and Neuberger 2001). In the 1990s, however, this system has come under increasing criticism within Germany as being unsuitable for promoting young and high-tech firms. Thus, the lack of capital hindered young and innovative firms from competing with firms from other countries, especially the US and Great Britain.

As a response to this failure, a special segment of the Frankfurt stock exchange called the Neuer Markt was established in March 1997 with the aim to serve the needs of both investors and young companies involved in high-risk new technologies (Audretsch and Lehmann 2004a, b; Vitols 2001). In this article we describe the Neuer Markt as an institutional mechanism to provide young and hightech firms with equity. However, we also point to the dark side of this institution: The dramatic number of delistings due to fraud and insolvencies of those companies led the Deutsche Boerse AG to terminate the Neuer Markt in 2003. From an institutional point of view - a huge amount of firms met the same fate than the Neuer Markt did: They disappeared. Thus, we analyze in the second part of the paper, the initial sample of firms listed on the Neuer Markt until his final termination.

The rest of the paper is organized as follows. In the next section we describe the Neuer Markt as an institution to give young and innovative firms access to equity capital and thus allowing them to emerge and grow. In "The Neuer Markt as an institution for creative destruction", we analyze firm characteristics of young and innovative firms necessary to survive on the stock market. "Surviving and nonsurviving firms on the Neuer Markt" provides some descriptive statistics and the empirical results. "Summary and conclusion" summarizes and concludes.

\section{The Neuer Market as an institution for access to equity capital}

On March 10th, 1997, the Deutsche Boerse AG founded the Neuer Markt as a privately organized market, which was at least at a rhetorical level modeled on the US's National Association of Securities Dealers Automated Quotations (NASDAQ), as a separate segment of the Frankfurt Stock Exchange. A number of features were included that were designed to meet the needs of institutional investors in small, young, and high-growth firms and in particular to gain investors' trust (Vitols 2001; Burghoff and Hunger 2004). Thus, the listing guidelines were even higher than those for an admission to the Official Trading. Important aspects of the Neuer Markt were the waiver of minimum requirements regarding the age of IPO candidates, the need 
to inaugurate at least two designed sponsors which were responsible for guaranteeing liquidity and tradability of the shares, and as an important aspect, the requirements for greater transparency in the form of quarterly financial reporting on the basis of either US-General Accepted Accounting Principles (GAAP) or International Accounting Standards (IAS). Additional requirements concerned the minimum nominal value of issue $(250,000 €)$, the minimum number of shares $(100,000)$, an equity capital of the issuer of at least 1.5 Mio. $€$, and an aggregated market price of the issue that amounts to at least 5 Mio. $€$. The issuer should have had a track record of at least 3 years and in general the free-float of the issue had to be at least $25 \%$ of the aggregated nominal volume (Burghoff and Hunger 2004). The issuer also had to submit a prospectus in accordance with the Securities Prospectus Regulation, which included additional information concerning sources and application of funds, affiliated enterprises, profits, losses and dividends per share, and information about risk factors. Such information is seen to be crucial for investors to asses the risk of the respective issue.

Those efforts of the Deutsche Boerse AG to establish high a reputation for the Neuer Markt led to an explosion in the number of newly listed firms. While a year with about 30 initial public offerings (IPOs) would have been seen as quite active before, the number of IPOs exploded. While at the beginning, ten firms went public on the Neuer Market in 1997, this number increased from 39 firms in 1998 to 117 firms in 1999 and to 120 firms in the year 2000. By the end of 2000, there were 338 companies listed on the Neuer Market with high a concentration in the sectors technology (20\%), Internet (20\%), and Software (15\%). And, interestingly, about one-sixth of the firms were based outside Germany. The great success of the Neuer Markt could also be estimated from the fact that the Neuer Market alone accounted for considerably more than half of the total market capitalization of Europe's new growth markets or stock exchange segments for young and high-tech firms (see Figs. 1 and 2).

This enormous success has given rise to the claim that Germany is catching up with the US with respect to the high-technology gap (Vitols 2001, p. 558), corresponding to regional agglomerations such as Munich ("Isar Valley"), Hamburg, or Frankfurt (Audretsch et al. 2006).

However, the crisis of the Neuer Market began in early 2000, when numerous companies had to confess that they would miss their forecasts from the prospectuses and other publications. Then, in September 2000, the first company listed at the Neuer Market declared itself bankrupt. Further bankruptcies and insolvencies followed and several of the distressed or insolvent companies applied for a listing in other market segments to relinquish their listings at the Neuer Markt. At the same time, the Deutsche Boerse AG announced to strike penny-stocks and insolvent companies from the stock list effective October 1st, 2001. From then on, the number of firms leaving the Neuer Markt increased dramatically. At the end of 2002, a total of 119 firms, more then one third of all listed companies, had left the Neuer Markt.

The fact that until the beginning of 2000 relatively fewer companies had been delisted from the Neuer Markt compared to the NASDAQ was explained by the higher quality requirements of the Deutsche Boerse AG. However, this image changed rapidly in the following years when the percentage of delisting companies perfectly matched the US-standard. The main reason was a phenomenon which had 


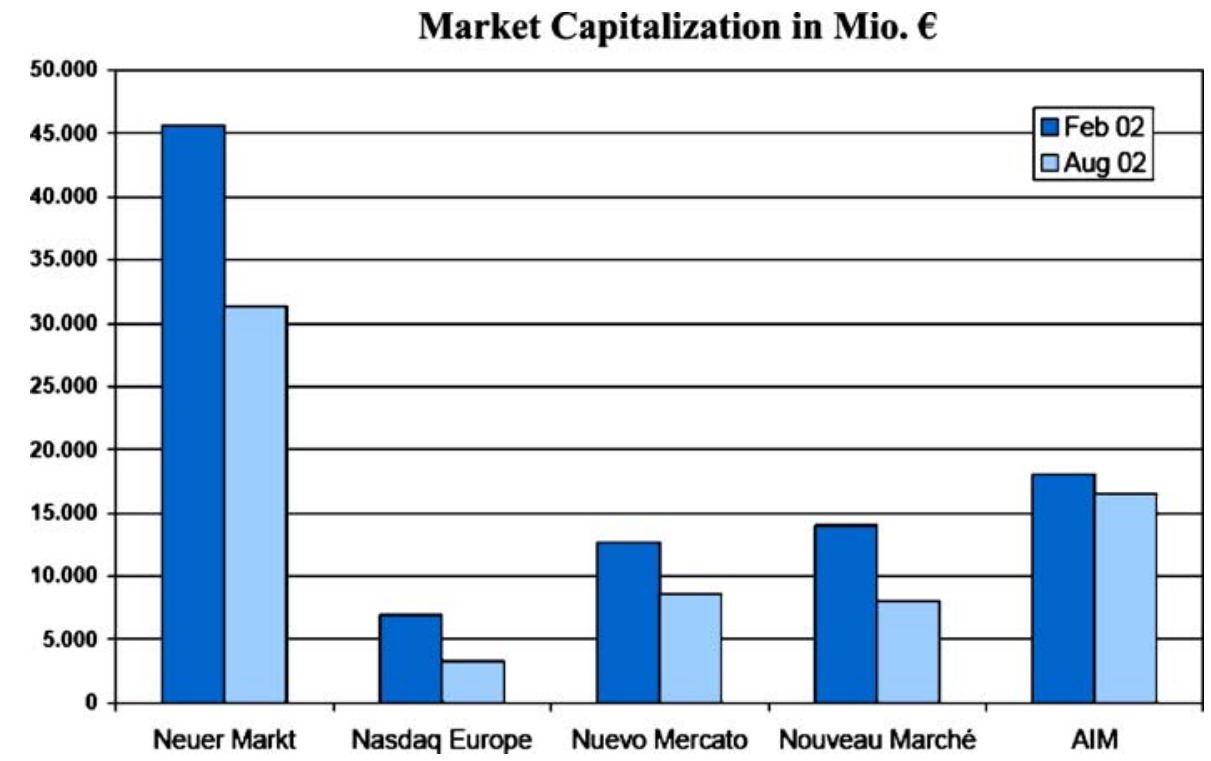

Fig. 1 Market capitalization of selected European new markets (source: Deutsche Boerse AG)

rarely been observed in Germany at that time: Fraud. In combination with stock options for top management, the number of suspected insider-trading and fraud increased drastically (Audretsch and Lehmann 2004a, b). Thus, the value of the brand Neuer Markt became negative for both the firms listed at the Neuer Markt and the Deutsche Boerse AG itself. As a consequence, the Deutsche Boerse AG closed

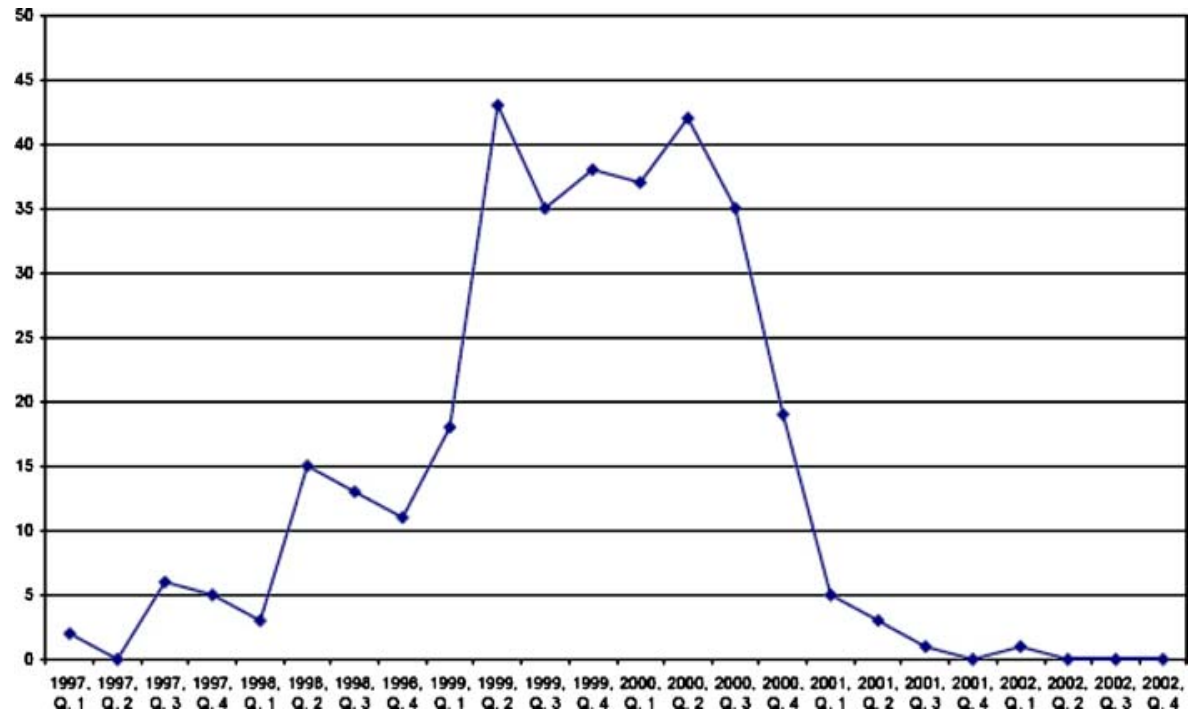

Fig. 2 Number of IPOs at the Neuer Markt from 1997-2002 (source: Deutsche Boerse AG) 
this market segment. Since January 1st, 2003, a totally new segmentation concept is in force, containing only two regulated markets, called General Standard and Prime Standard. The third element, the Unofficial Regulated Market keeps on trading. However, the latter is not a regulated market in the sense of the Investment Services Directive and until now remains what it was before: illiquid, and rather irrelevant for most domestic stocks (Burghoff and Hunger 2004).

\section{The Neuer Markt as an institution for creative destruction}

Providing access to equity capital for high-growth firms is only one side of the medal of stock markets as an economic institution. The other side of the medal is that stock markets also serve as an institution to reallocate productive resources from non-surviving firms to surviving firms. Schumpeter (1942) introduced the famous metaphor of "creative destruction" by claiming that the problem is how capitalism administers existing structures, whereas the relevant problem is how it creates and destroys them. Stock markets such as the Neuer Market or the NASDAQ could then be interpreted as the main institution in a capitalist system to create and destroy existing structures.

Firms contain productive resources that allow them to compete in their product market. Those resources could be physical, intangible, like patents, or tacit, like specialized knowledge of market or production processes. When firms use these resources inefficiently - either because of bad luck or mismanagement - a firm's value will be low relative to the value of its productive process. As a consequence, firms which use their resources not in the best way should show lower survival rates at the stock markets. Thus, we should expect takeovers as well as delistings due to financial distress to be more likely for poorly performing firms. However, even successful firms may not be using their resources in the most productive way possible and they also could be taken over and have their resources reallocated to firms that will utilize them even more efficiently.

The process by which firms disappear from the stock market is not well understood. Baker and Kennedy (2002) provide a framework analyzing firm characteristics among surviving and non-surviving firms traded on the New York and American Stock Exchanges. They find that the "economic grim reaper" (p. 2) kills at least underperforming firms. Fama and French (2001) use IPO data from the NASDAQ and find that new lists are delisted for poor performance at much higher rates than all firms, and that only about one out of three new lists survived for 10 years. As mentioned above, only one out of three new lists survived for 5 years on the Neuer Markt in Germany as well.

In the following, we will analyze some factors explaining the differences between surviving and non-surviving firms on the Neuer Markt by following the framework of Baker and Kennedy (2002) that stock markets are an important institution to reallocate productive resources. In particular, we analyze firm specific variables such as age and size, the impact of management quality and corporate governance variables, and, especially, the impact of intangible and tacit resources.

Since this paper is more or less descriptive than theoretically driven, we renounce testing explicitly formulated hypotheses. 


\section{Surviving and non-surviving firms on the Neuer Markt}

To analyze systematically the differences between surviving and non-surviving firms on the stock market, we use a unique dataset of 341 firms listed on the Neuer Markt in Germany from 1997 until 2002. This dataset is collected combining individual balance sheet data from IPO prospectuses, publicly available information from online data sources including the German Patent Office, the Deutsche Boerse AG, and information from newspapers to get further information on the kind of delistings. Since the start of the Neuer Markt, 74 firms have been delisted. Although the Deutsche Boerse AG considered delisting "penny stocks" similar to the NASDAQ before June 2002, the firms in this database are not affected by the penny-stock rules $^{1}$. These 74 firms were banned from the Neuer Markt because they broke the rules $^{2}$ or because of declarations of insolvency, takeovers or voluntarily delistings ${ }^{3}$ since the costs of being listed at the "Neuer Markt" exceeded expected future benefits. A delisting from the Neuer Markt automatically leads to a listing at the Regulated Market, which is a market segment with low stringent requirements and which is also perceived as less attractive to the companies as fewer analysts look at this segment. Small firms with high a probability of generating future cash flows are willing to pay a significant fee (about 250,000 € per year) to be listed on the Neuer Markt since it increases the probability of raising new capital in the future.

The number and kind of delistings as well as all the IPO-Data are provided by the Deutsche Boerse $A G$ (www.deutsche-boerse.com). We use the months that a company succeeded on the Neuer Markt since the first listing (IPO-Date) as the endogenous variable. Since the market - and the number of listings and delistingswas highly dynamic over this period, we use the number of months instead of years. The number of employees is used as a measure for the firm size prior to its IPO. The difference in size before and after the IPO of the firm constitutes the growth rate of employees (as measured by the difference of the natural logarithm). Further information from IPO data are the age of a firm (as measured in years before being listed on the stock market) and the names and titles of the executives and the board members. The variable Board Human Capital measures the number of directors with an academic degree (either doctor or professor). Data on the ownership structure are also taken from the IPO prospectus information. We include the ownership concentration of the CEO, the board of directors, friends and families, and venture capitalists, by including the variables Executive Ownership, Director Ownership, Venture Capital Ownership, and Friends \& Family Ownership. Ownership con-

\footnotetext{
${ }^{1}$ The new "penny stock" rule will delist firms if the average price for the admitted shares on exchange days is less then $1 €$ per share for a period of 30 consecutive exchange days and the relevant company's market capitalization is less then $20 \mathrm{M} €$ (see www.deutsche-boerse.com).

${ }^{2}$ For example, they could not present annual balance sheet data although they were admonished several times and had to pay a penalty or showed criminal misbehavior such as insider trading or fraud.

${ }^{3}$ This occurs in cases where the designated sponsors close their relationships and stop securing a certain amount of volatility of the shares. The abundance of the sponsorship serves as a signal of low quality and expected low performance in the future. Also some firms quit the market voluntarily because they are no longer able to pay the costs of staying at the Neuer Markt.
} 
centration is measured by the Herfindahl Index. Since patents are not included in the annual reports, we use the database from the Deutsche Patentamt (www.dpma.de) to identify patent activity. Thus, we are able to control for whether the patent is owned by the CEO or the firm by including the variables Firm Patents and Executive Patents.

The results from two-tailed $t$-tests are shown in Table 1 . We start by analyzing firm age, size and past growth rates as determinants of what affects firm survival. ${ }^{4}$ As shown in Table 1, firm age significantly differs among surviving and nonsurviving firms. Since entry and exit rarely occur in one time period, the age of the firms influences their survival rates as expressed by the struggle of survival or the Darwinian survival of the fittest. Thus, the age of a firm can easily be interpreted as its ability to have survived until the current period. The duration of survival depends on a firm's ability to learn about its own production and cost functions and to react to changes on the supply or demand side (Audretsch 1995). The age of a firm captures learning-by-doing and changes in average stock of endowments of successive age cohorts (Agrawal and Gort 2002). The stock of such learning accumulates with a firm's age (Audretsch 1995). Firms enter the market with incomplete knowledge about the quality of their endowments, managerial capabilities and of their products and services and they learn progressively as they produce (Jovanovic 1982; Hopenhayn 1992). Younger firms will therefore be associated with a higher risk than older ones. Thus, firm age seems to be a significant factor that positively influences the likelihood of survival for new firms (Caves 1998; Sutton 1997).

Firm survival is also determined by size. A firm can only survive when the revenues are large enough to cover the costs. With imperfect competition, a positive price-cost margin can only be sustained by a natural monopoly, lower average cost functions compared to the competitors, collusion, and any kind of market power and strategic competition which prevents entry or pushes exits. Most of these advantages are strongly correlated to firm size. Since entry is associated with sunk costs, young and small firms lose a huge amount of their scarce financial resources before they enter the product market. The only way to survive is to grow and attain a minimum size that allows them to compete or collude with incumbent firms. However, neither the numbers of employees as a measure of size nor the growth rates in the first year after IPO differ significantly among surviving and non-surviving firms. Nevertheless, both the growth rates and the numbers of employees are higher for surviving firms.

\footnotetext{
${ }^{4}$ There is only a small number of theoretical papers analyzing the effects of age, size, and growth on firm survival. Jovanovic (1982) developed a learning model where "age" captures the experience of a firm and thus is the major determinant of firm survival. In contrast, Hopenhayn (1992) showed that size is the main dimension of heterogeneity of firms and thus determines firm survival positively. Recently, Cooley and Quadrini (2001) showed that age and growth are no independent factors of firms (see also Audretsch et al. 2006a). They parameterize their model and show that size affects firm survival positively, while the influence of Firm survival is also determined by size. A firm can only survive when the revenues are large enough to cover the costs. With imperfect competition, a positive price-cost margin can only be sustained by a natural monopoly, lower average cost functions compared to the competitors, collusion, and any kind of market power and strategic competition.
} 
Table 1 Descriptive statistics of the exogenous variables

\begin{tabular}{|c|c|c|c|c|}
\hline \multirow[b]{2}{*}{ Variable } & \multicolumn{2}{|l|}{ Mean } & \multicolumn{2}{|l|}{ Min/Max } \\
\hline & Delisting & Surviving & Delisting & Surviving \\
\hline Age $(* * *)$ & $7.656(8.255)$ & $11.06(11.738)$ & $1(52)$ & $1(107)$ \\
\hline Employees before IPO (Size) & $198.29(293.323)$ & $217.71(397.567)$ & $2(1700)$ & $3(3030)$ \\
\hline Employees after IPO & $289.89(364.27)$ & $326.38(465.308)$ & $3(3683)$ & $12(1873)$ \\
\hline Growth rate & $0.58(1.76)$ & $0.47(1.57)$ & $-3.0(5.0)$ & $-4.0(8.0)$ \\
\hline \multicolumn{5}{|l|}{ Ownership } \\
\hline Executive ownership & $37.07(33.06)$ & $35.2(31.708)$ & $0(100)$ & $0(100)$ \\
\hline Board ownership & $7.11(15.08)$ & $7.87(17.26)$ & $0(63)$ & $0(100)$ \\
\hline Friends, family ownership & $59.66(34.12)$ & $54.81(35.14)$ & $0(100)$ & $0(100)$ \\
\hline Venture capitalists ownership $(* *)$ & $10.94(17.82)$ & $14.32(22,33)$ & $0(90)$ & $0(100)$ \\
\hline Firm patents $(* *)$ & $2.15(8.15)$ & $4.73(15.36)$ & $0(50)$ & $0(142)$ \\
\hline CEO patents $(* * *)$ & $0.41(2.438)$ & $2.59(9.408)$ & $0(20)$ & $0(50)$ \\
\hline Human capital executives $(* * *)$ & $0.36(0.677)$ & $0.61(0.857)$ & $0(3)$ & $0(5)$ \\
\hline $\begin{array}{l}\text { Executive ownership human } \\
\text { capital with title }(* * *)\end{array}$ & $0.12(.241)$ & $0.41(0.241)$ & $0(5)$ & $0(5)$ \\
\hline Human capital board & $1.38(1.210)$ & $1.49(0.270)$ & $0(100)$ & $0(100)$ \\
\hline
\end{tabular}

$(*, * *, * * *)$ means significant test of equality of means (variance). $T$-test for equality of means under equal variances if (Levine's test for equal variances) $p \leq 0.10$

It is widely claimed that productive resources are often used inefficiently due to mismanagement. Thus, we expect that surviving firms differ from non-surviving firms on their corporate governance structure. Since the allocation of ownership directly influences the incentives, ownership would provide a strong incentive for executives to behave in the interest of other shareholders and thus increase the value of the firm (Jensen and Meckling 1976). Following the theoretical arguments and the empirical findings, ownership could provide an incentive for executives to run a firm and thus decrease the failure of a firm. If the firm is bankrupt, manager owners loose their private benefits of control and their sources of future income (Lehmann 2006). Thus, ownership serves as an incentive mechanism for managers to take actions that prevent firm failures.

Ownership shares for directors also may reduce agency problems. First, ownership may increase the independence of board members from managers and thus fosters the possibility and incentive to control them independently. Also, the free-rider problem may be overcome if directors have ties to the firm and thus a strong interest in the company's well being (Shivdasani 1993). The longer the firm survives on the stock market, the longer directors generally have their seats on the board and the associated directorship income without the financial loss of all their equity. Thus, we expect that ownership by the governing board members should be higher in surviving firms.

Finally, by providing equity, venture capitalists play a major role in the governance structure of young and high-tech firms (Audretsch and Lehmann 2004a, b). Ownership by venture capitalists may increase their incentives to invest in information collecting and monitoring activities (Lehmann 2006). They may also be 
more likely to strengthen the management teams as their control rights via ownership increase.

The results, however, show no differences in the distribution of ownership shares among surviving and non-surviving firms, neither for the shares held by CEOs, nor for board and friends and family members. Only the shares held by venture capitalists differ significantly. The results show that venture capitalists hold a significantly higher amount of shares in surviving firms. However, the causality of this result is not obvious. On the one hand, venture capitalists select the most promising firms before IPO and, on the other hand, serve as strong monitors for the management (Audretsch and Lehmann 2004a, b; Lehmann 2006).

Finally, and perhaps most important, firm value strongly depends on the existence of productive resources. Especially high-technology firms are characterized by their intangible or tacit resources. While intangible resources are more or less linked to patents or brand names, tacit resources strongly depend on the human capital of managers and employees.

Human capital is assumed to play a dominant role in founding new firms in the high-technology sector (Audretsch and Stephan 1996; Zucker et al. 1998). Bates (1990) shows that an owner's educational background is a major determinant of failure of small business firms and reports that highly educated entrepreneurs are less likely to fail. Thus, we expect that surviving firms differ from delisted firms in the educational background of top management. The same should be observed for the board of directors. They play an important role by providing information and advice to managers. So managers may have an incentive to choose board members with high specialized human capital (Audretsch and Lehmann 2006b). Our results provide strong evidence that especially the human capital of the leading manager - the $\mathrm{CEO}$ - significantly differs among surviving and non-surviving firms. Thus, from a resource based view of the firm, the human capital of the CEO is one of the most critical resources for firm survival.

Patents are one exceptional example of intangible assets or resources for which property rights are to some extent defined and protected by existing legal systems. A firm's patents may also be the output of a kind of "knowledge production function," with human capital and corporate culture as intangible and spending in R \& D as monetary inputs. Finally, patents may give a kind of monopoly to small firms which allows for extraordinary future cash flows. Thus, we expect that surviving firms differ significantly from delisted firms in the number of patents.

The results show that surviving firms own significantly more patents per firm. While a delisted firm owns only two patents on average, the average number of patents owned by surviving firms is at least twice as many. Surviving firms also are characterized by higher numbers of managers and directors with academic degrees.

\section{Summary and conclusion}

We introduced and described the Neuer Markt as an institution to create and destroy organizational structures. Although stock markets like the Neuer Markt are often seen as a means to give young and innovative firms access to equity capital, they 
also act as a filtering mechanism which separates "the good from the bad". By doing this, they reallocate productive resources from non-surviving firms to surviving firms. Such reallocation occurs through the liquidation of non-surviving firms and takeovers.

We examined whether and how surviving firms differ from non-surviving or delisted firms. Our analysis documents several findings. Surviving firms are significantly older, show a higher amount of equity hold by venture capitalists, own more or at least twice as many patents and in most cases CEOs possess an academic degrees.

At the beginning of the paper, we mentioned that the Neuer Markt was closed by the Deutsche Boerse AG. At this time, most of the firms could be called pennystocks. In contrast to the US - the NASDAQ still exists - the Neuer Markt was only seen as an institution to give young firms access to equity but not as a means to select among the more or less promising projects. What about the surviving pennystocks? A lot of them increased their market values by more than $1000 \%$ in the past 5 years. At the time of IPO, most of them had nothing than a few ideas and some patents. The Neuer Markt gave them expanded access to equity capital, allowing them to emerge and grow. On the other hand, this stock market segment led to a destruction of firms and selected from the bulk of dotcom companies only those which are able to use their resources in an efficient way and thus allowing the surviving firms to grow on a natural basis.

However, what happened with the Neuer Markt? The deutsche Börse AG closed the Neuer Markt in 2003 because its main asset - reputation — seemed to be damaged due to fraud, insider trading and potential adverse selection effects. Thus, the value of the Neuer Markt became negative for both the firms listed and the Deutsche Börse AG. The Neuer Markt as an institution to allow young and innovative growth firms to go public was quit the right way although this institution failed to serve as a quality signal for actual and potential equity providers. Thus, since January 1st, 2003, the Deutsche Börse AG created a totally new segment concept containing only two regulated markets: the general Standard and the Prime Standard. ${ }^{5}$ Already listed companies enter the General Standard automatically. An issuer from the General Standard can apply for entering the Prime Standard if she meets additional requirements. Interestingly, most of these additional requirements are mainly drawn from the Neuer Markt.

Summing up - the Neuer Markt as an institution served the same fate as the firms listed on this stock market segment. It was created to serve as means to provide young and risky firms with equity. And it was destroyed by the same firms. However, the basic idea - a stock market segment for young and innovative firmsstill lives on since the largest high-tech companies are integrated into the TecDAX. This index contains mainly the same firms which are covered by the NEMAX-50, the index of the formerly Neuer Markt.

\footnotetext{
${ }^{5}$ The third element, the Unofficial Regulated Market (Freiverkehr) keeps on trading (see Burghoff and Hunger 2004).
} 
Acknowledgments For helpful comments we would like to thank Alexander Starnecker and an anonymous referee.

\section{References}

Agrawal, R., \& Gort, M. (2002). Firm and product life cycles and firm survival. American Economic Review (Papers and Proceedings), 92, 184-190 (May).

Audretsch, D. B. (1995). Innovation and industry evolution. Cambridge: MIT.

Audretsch, D. B., Keilbach, M., \& Lehmann, E. E. (2006). Entrepreneurship and growth. Oxford: Oxford University Press.

Audretsch, D. B., \& Lehmann, E. E. (2004a). Debt or equity: The role of venture capital in financing hightech firms in germany. Schmalenbach Business Review, 56, 340-357.

Audretsch, D. B., \& Lehmann, E. E. (2004b). Option programmes for top managers and scandals on the stock exchange. Stock Option Watch, May 2004, 4-6.

Audretsch, D. B., \& Lehmann, E. E. (2006). Entrepreneurial access and absorption of knowledge spillovers: Strategic board and managerial composition for competitive advantage. Journal of Small Business Management, 44(2), 155-166.

Audretsch, D. B., \& Stephan, P. (1996). Company-scientist locational links: The case of biotechnology. American Economic Review, 86(3), 641-652.

Baker, G. P., \& Kennedy, R. E. (2002). Survivorship and the economic grim reaper. Journal of Law, Economics and Organization, 18(2), 324-361.

Bates, T. (1990). Entrepreneurial human capital impacts and small business longevity. The Review of Economics and Statistics, 72, 551-559.

Burghoff, H. P., \& Hunger, A. (2004). The Neuer Markt - an (overly) risky asset of Germany's financial system. Advances in Financial Economics, 10, 295-324.

Caves, R. (1998). Industrial organization and new findings on the turnover and mobility of firms. Journal of Economic Literature, 36(4), 1947-1982.

Cooley, T. F., \& Quadrini, V. (2001). Financial markets and firm dynamics. American Economic Review, 91(5), 1286-1310.

Fama, E., \& French, K. R. (2001). Newly listed firms, fundamentals, survival rates, and returns. Center for Research in Security Prices, working paper no. 530. Chicago: Chicago University Press.

Hopenhayn, H. A. (1992). Entry, exits, and firm dynamics in long run equilibrium. Econometrica, 60(5), 1127-1150.

Jensen, M. C., \& Meckling, W. (1976). Theory of the firm. Managerial behavior, agency costs and ownership structures. Journal of Financial Economics, 3, 305-360.

Jovanovic, B. (1982). Selection and the evolution of industry. Economica, 50(3), 649-670.

Lehmann, E. E. (2006). Does venture capital syndication spur employment growth and shareholder value. Small Business Economics, 26, 455-464.

Lehmann, E. E., \& Neuberger, D. (2001). Do lending relationships matter? Evidence from bank survey data in Germany. Journal of Economic Behavior and Organization, 45, 339-359.

Schumpeter, J. A. (1942). Capitalism, Socialism and Democracy. New York: Harper and Row.

Shivdasani, A. (1993). Board composition, ownership structure, and takeovers. Journal of Accounting and Economics, 16(1/2/3), 167-198.

Sutton, J. (1997). Gibrats legacy. Journal of Economic Literature, 35(1), 40-59.

Vitols, S. (2001). Frankfurt's Neuer Markt and the IPO explosion: is Germany on the road to silicon valley. Economy and Society, 30, 553-564.

Zucker, L. G., Darby, M. R., \& Brewer, M. B. (1998). Intellectual human capital and the birth of U. S. biotechnology enterprises. American Economic Review, 88(1), 290-306. 